\title{
Synthesis of a Sulfonimidamide-Based Analog of Tasisulam and Its Biological Evaluation in the Melanoma Cell Lines SKMel23 and A375
}

\author{
Anne-Dorothee Steinkamp ${ }^{a} \quad$ Laurenz Schmitt $^{b} \quad$ Xiaoyun Chen $^{a}$ \\ Katharina Fietkau $^{\mathrm{b}}$ Ruth Heise ${ }^{\mathrm{b}}$ Jens M. Baron ${ }^{\mathrm{b}}$ Carsten Bolm ${ }^{\mathrm{a}}$ \\ ${ }^{a}$ Institute of Organic Chemistry and ${ }^{b}$ Clinic for Dermatology and Allergology, RWTH Aachen University, \\ Aachen, Germany
}

\section{Keywords}

A375 cell line · Antiproliferative effect - LY573636 · SKMel23

cell line · Sulfonimidamide - Tasisulam · Melanoma ·

Chemotherapy

\begin{abstract}
Tasisulam is a promising antitumor agent with complex pharmacology, which is used as an antiproliferative agent in patients with metastatic melanoma and other solid tumors. Phase 2 melanoma studies showed promising results but had to be stopped because of insufficient tasisulam clearance leading to toxic side effects. To reduce the negative effects of tasisulam, we synthesized a novel sulfonimidamidebased analog to evaluate its antiproliferative effects in comparison to the original compound by performing a cell proliferation assay in melanoma cell lines SKMel23 and A375. The results revealed that the analog had inhibitory effects on the proliferation comparable to tasisulam in both investigated cell lines. These results could contribute to a reduced toxicity of tasisulam and lead to further clinical trials in metastatic melanoma.

(c) 2016 S. Karger AG, Basel
\end{abstract}

Anne-Dorothee Steinkamp and Laurenz Schmitt contributed equally to this work.

\section{Introduction}

Although comprising only approximately $4 \%$ of all skin cancer cases, melanoma is still responsible for almost $80 \%$ of skin cancer deaths $[1,2]$. The combination of targeted therapy with BRAF and MEK inhibitors has become the standard of care in patients with BRAF (V600E) mutant melanoma and can be used in about one half of patients but they mostly develop resistance a few months after initiation [3-5]. Approximately $19-58 \%$ of patients with metastasis of melanoma benefit from a systemic immunotherapy, depending on mono- or combination therapy $[6,7]$. Ipilimumab targets the cytotoxic T-lymphocyte-associated protein 4 (CTLA-4) receptor whereas nivolumab and pembrolizumab target programmed cell death protein 1 (PD-1) receptors, which has been proven to be superior to ipilimumab alone. The combination of ipilimumab and nivolumab has yielded higher response rates, greater tumor shrinkage, and longer progression-free survival than monotherapy alone [7-9]. However, novel effective therapies for patients with metastatic melanoma are required but have remained scarce. Especially in chemotherapy new developments and insights are missing. A phase 2 study of tasisulam achieved partial response, with an objective response rate (RR) of $11.8 \%$ in 8 of 68 patients with

Prof. Dr. rer. nat. Carsten Bolm

Institute of Organic Chemistry, RWTH Aachen University

Landoltweg 1

DE-52056 Aachen (Germany)

E-Mail Carsten.Bolm@oc.rwth-aachen.de 


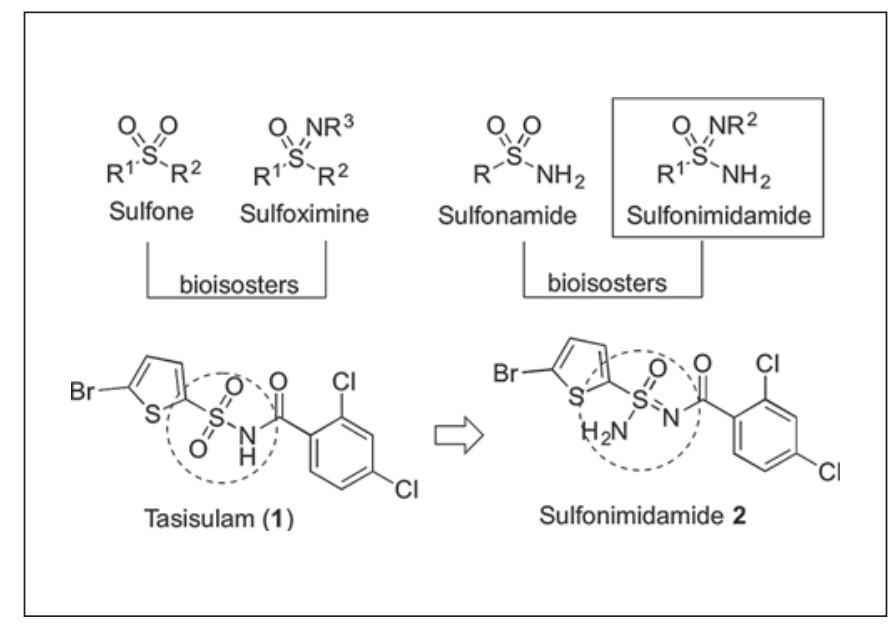

Fig. 1. Overview of structures related to sulfonimidamides.

second-line metastatic melanoma [10]. Tasisulam is an acyl sulfonamide with a unique antitumor dual mechanism of action, involving antiangiogenesis and mitotic inhibition [11]. An in vitro, antitumor screening analysis conducted by the National Cancer Institute (NCI COMPARE analysis) demonstrated a broad range of activity for tasisulam in 60 tumor cell lines including leukemia, melanoma, non-small-cell lung cancer, colon, ovarian, renal, and breast cancers [12]. Subsequently, tasisulam was evaluated as a single agent in several tumor types [10, 13-16]. In this study we focused on the antiproliferative effect of tasisulam and a newly synthesized sulfonimidamide-based analog, which both were studied in melanoma cell lines in vitro.

It is already known that isosteric replacements in bioactive effector molecules are of interest in medicinal chemistry [17]. Along these lines, we focused on the formal conversion of a sulfone into a sulfoximine through substitution of a sulfonyl group by a sulfoximidoyl moiety (Fig. 1) [18]. As a result, various compounds with good cyclooxygenase- 2 inhibition potency were obtained [19$21]$. In addition, we studied sulfoximine-based analogs of zolimidine [22], dapsone [23], and S0859 [24]. The most advanced examples stem from industry, where BayerPharma [25] and AstraZeneca [26] have promoted kinase inhibitors with sulfoximidoyl groups in their respective anticancer programs to clinical trials [27]. Switching from a sulfone to a sulfoximine allows retaining the drug effectiveness while improving the overall bioactivity profile by positively affecting solubility [28] and ADME properties [29].
Sulfonamides are important compounds in medicinal chemistry [30-40], and, in particular, $\mathrm{N}$-acylated derivatives have revealed interesting antitumor activities in combination with attractive pharmacokinetics $[41,42]$. As surrogates for sulfonamides, the corresponding sulfonimidamides have lately been promoted (Fig. 1). For example, Sehgelmeble et al. [43] found significant potencies when profiling sulfonimidamide-based analogs of sulfonamidic $\gamma$-secretase inhibitors. Furthermore, $\mathrm{N}$-acylated sulfonimidamides were shown to have bioisosteric properties to carboxylic acid [44-49].

Although the first sulfonimidamide syntheses date back to the 1960s [50-55], the preparative chemistry related to such compounds has remained rather underdeveloped mainly due to the difficulties in accessing appropriately substituted core structures. Only recently have Arvidsson and others significantly advanced the field by applying modern catalytic protocols for sulfonimidamide modifications [56-60]. With respect to applications of sulfonimidamides as reagents in synthesis and catalysis, the early work by the groups of Malacria [61-63] and Dodd [64-67] is noteworthy. We made use of sulfonimidamides in organo- [68] and metal catalysis [69, 70], which, in part, required the development of new synthetic protocols [71-75].

Tasisulam (compound 1, LY573636) is an N-acyl sulfonamide with antiproliferative activity developed by Eli Lilly $[11,41,42]$. In various tumor xenograft models, it showed potent efficacy in vivo inducing apoptosis and exhibiting antiangiogenesis activity. Being considered as a promising anticancer agent $[13,76]$, a robust process was introduced providing sufficient material for the initiated clinical trials $[77,78]$. Due to safety concerns, however, the compound development was terminated, which also affected a phase 3 study focused on tasisulam treatments of patients with metastatic melanoma [79].

To the best of your knowledge, the sulfonimidamide analog of tasisulam (compound 1), i.e. compound 2, has neither been prepared nor screened on bioactivity. (Note that our first experiments were performed in April 2014. On November 19, 2014, a paper on sulfonimidamide chemistry by Wakchaura et al. [58] appeared online, which seemed to indicate that they were thinking along the same lines.) In the light of the interesting cytotoxic properties of the parent compound and the expertise of our group in sulfur chemistry, we decided to prepare sulfonimidamide compound 2 and to analyze its antiproliferative properties in the melanoma cell lines SKMel23 and A375. 


\section{Materials and Methods}

\section{Chemistry}

General

Flash column chromatography (FCC) was performed with silica gel $60(63-200 \mu \mathrm{m})$ purchased from Merck. For thin-layer chromatography, aluminum sheets with silica gel $60 \mathrm{~F}_{254}$ (Merck) were utilized, and the products were visualized by treatment with aqueous potassium permanganate or $n$-butanolic ninhydrin solutions.

Nuclear magnetic resonance (NMR) spectra were recorded on an Agilent VNMRS $400\left({ }^{1} \mathrm{H}-\mathrm{NMR}: 400 \mathrm{MHz},{ }^{13} \mathrm{C}-\mathrm{NMR}: 101\right.$ $\mathrm{MHz})$ or an Agilent VNMRS $600\left({ }^{1} \mathrm{H}-\mathrm{NMR}\right.$ : $600 \mathrm{MHz},{ }^{13} \mathrm{C}-\mathrm{NMR}$ : $151 \mathrm{MHz}$ ) spectrometer. Carbon spectra were recorded decoupled. The chemical shifts $\delta$ are given in parts per million (ppm), and the residual solvent peak of the nondeuterated solvent was used as reference $\left[\left(\mathrm{CH}_{3}\right)_{2} \mathrm{CO}:{ }^{1} \mathrm{H}-\mathrm{NMR}: \delta=2.05 \mathrm{ppm},{ }^{13} \mathrm{C}-\mathrm{NMR}\right.$ : $\left(\mathrm{CD}_{3}\right)_{2} \mathrm{CO}: \delta=29.84 \mathrm{ppm} ;\left(\mathrm{CH}_{3}\right)_{2} \mathrm{SO}:{ }^{1} \mathrm{H}-\mathrm{NMR}: \delta=2.50 \mathrm{ppm}$, $\left.{ }^{13} \mathrm{C}-\mathrm{NMR}:\left(\mathrm{CD}_{3}\right)_{2} \mathrm{SO}: \delta=39.5 \mathrm{ppm}\right]$. The multiplicity was reported with the following abbreviations: brs = broad singlet, $s=$ singlet, $\mathrm{d}=$ doublet, $\mathrm{m}=$ multiplet, and coupling constants were given in hertz. Note: signals in the carbon spectra recorded on Agilent VNMRS $600(\delta=78 \mathrm{ppm})$ are artifacts and do not belong to the molecule.

Infrared spectra (IR) were recorded on a PerkinElmer Spectrum 100 spectrometer using the attenuated total reflectance (ATR) technique. The wave number $v$ is given per centimeter.

Mass spectra were recorded on a Finnigan SSQ 7000 spectrometer [electron ionization (EI), $70 \mathrm{eV}$; chemical ionization (CI), 100 $\mathrm{eV}$ ]. For high-resolution mass spectra (HRMS), a Thermo Fisher Scientific LTQ Orbitrap XL spectrometer [electrospray ionization (ESI) in positive ion mode] was used. The resulting signals are given according to their $\mathrm{m} / z$ values, and their relative intensity is reported in parentheses. Elementary analysis was performed on an Elementar Vario El instrument.

Anhydrous solvents were freshly distilled in a moisture-free atmosphere with adequate drying reagents or purchased. If not mentioned differently, the common Schlenk technique was applied. Purchased chemicals were used without further purification. DMSO was from Calbiochem (Darmstadt, Germany). Tasisulam was purchased from Selleckchem (Munich, Germany).

Compounds 2 [72], 4 [43], 7 [43] and 8 [72] were synthesized in analogy to reported protocols.

\section{Preparative Protocols and Analytical Data}

$N$-[(5-Bromothiophen-2-yl)sulfinyl]-2,4-dichlorobenzamide (Compound 2). In an oven-dry flask, compound 8 (100 mg, 0.23 $\mathrm{mmol})$ was diluted in dry $\mathrm{CH}_{3} \mathrm{CN}(10 \mathrm{~mL})$, and hexamethyldisilazane $(0.10 \mathrm{~mL}, 0.46 \mathrm{mmol})$ was added. The mixture was stirred for $9 \mathrm{~h}$ at room temperature, and after the solvent had been removed under reduced pressure the mixture was directly subjected to column chromatography. Sulfonimidamide compound 2 was obtained after purification by FCC ( $n$-pentane:ethyl acetate $=3: 1)$ as a white solid. The yield was $78 \%$. MP $129-131^{\circ} \mathrm{C}$ (decomposition). ${ }^{1} \mathrm{H}-\mathrm{NMR}$ [600 MHz, $\left.\left(\mathrm{CD}_{3}\right)_{2} \mathrm{CO}\right]: \delta=7.84(\mathrm{~d}, J=8.4 \mathrm{~Hz}, 1 \mathrm{H}), 7.68$ $(\mathrm{d}, J=4.1 \mathrm{~Hz}, 1 \mathrm{H}), 7.59$ (brs, $2 \mathrm{H}), 7.51(\mathrm{~d}, J=2.0 \mathrm{~Hz}, 1 \mathrm{H}), 7.42(\mathrm{dd}$, $J=8.4,2.0 \mathrm{~Hz}, 1 \mathrm{H}), 7.30(\mathrm{~d}, J=4.1 \mathrm{~Hz}, 1 \mathrm{H}) .{ }^{13} \mathrm{C}-\mathrm{NMR}[151 \mathrm{MHz}$, $\left.\left(\mathrm{CD}_{3}\right)_{2} \mathrm{CO}\right]: \delta=171.41,144.77,136.80,135.90,134.01$ (almost covered by the proximate peak, not visible in the edited spectrum), $133.90,133.04,131.67,130.91,127.72,120.47$. MS (EI): $m / z=414$
([M] $\left.]^{+}, 3\right), 211(13), 174(100), 145$ (57), 109 (52), 96 (17), 82 (56), 74 (65), 64 (45). MS (CI): $m / z=415\left([\mathrm{M}+\mathrm{H}]^{+}, 58\right), 381(71), 190$ (74). IR (ATR): $v=3,784,2,923,2,421,2,177,2,116,1,992,1,796$, $1,716,1,589,1,549,1,465,1,398,1,375,1,319,1,296,1,244,1,154$, $1,102,1,052,1,020,957,892,861,832,799,769,557$. HRMS (ESI): $\mathrm{m} / z$ calcd. for $\mathrm{C}_{11} \mathrm{H}_{7} \mathrm{BrCl}_{2} \mathrm{~N}_{2} \mathrm{O}_{2} \mathrm{NaS}_{2}$, 434.8402; found, 434.8405. Elemental analysis: calcd. for $\mathrm{C}_{11} \mathrm{H}_{7} \mathrm{BrCl}_{2} \mathrm{~N}_{2} \mathrm{O}_{2} \mathrm{~S}_{2}, 31.90$ (C), 1.70 $(\mathrm{H}), 6.76(\mathrm{~N})$; found, $32.17(\mathrm{C}), 1.90(\mathrm{H}), 6.58(\mathrm{~N})$.

Sodium 5-Bromothiophene-2-sulfinate (Compound 4). 5-Bromothiophene-2-sulfonylchloride ( $2.40 \mathrm{~g}, 9.21 \mathrm{mmol})$ was added to a solution of $\mathrm{Na}_{2} \mathrm{SO}_{3}(2.55 \mathrm{~g}, 20.3 \mathrm{mmol})$ and $\mathrm{Na}_{2} \mathrm{CO}_{3}(1.70 \mathrm{~g}, 16.6$ $\mathrm{mmol})$ in distilled water $(20.0 \mathrm{~mL})$. The mixture was heated to $80^{\circ} \mathrm{C}$ for $3 \mathrm{~h}$, and a white solid was obtained after the water had been removed. The residue was dissolved in ethanol $(30.0 \mathrm{~mL})$ and heated to $80^{\circ} \mathrm{C}$ for $1.5 \mathrm{~h}$. The suspension was filtered, and after evaporation of the filtrate the sodium salt compound 4 was obtained as a white crystalline powder. The yield was 99\%. MP: 330 $332^{\circ} \mathrm{C}$ (decomposition). ${ }^{1} \mathrm{H}-\mathrm{NMR}\left[600 \mathrm{MHz},\left(\mathrm{CD}_{3}\right)_{2} \mathrm{SO}\right]: \delta=7.01$ $(\mathrm{d}, J=3.6 \mathrm{~Hz}, 1 \mathrm{H}), 6.76(\mathrm{~d}, J=3.6 \mathrm{~Hz}, 1 \mathrm{H}) .{ }^{13} \mathrm{C}-\mathrm{NMR}[151 \mathrm{MHz}$, $\left.\left(\mathrm{CD}_{3}\right)_{2} \mathrm{SO}\right]: \delta=170.07,130.17,123.70,111.05$. MS (ESI-): $\mathrm{m} / z=$ 226 (M-, 100). IR (ATR): $v=3,602,2,947,2,657,2,325,2,175$, $2,114,1,993,1,761,1,433,1,405,1,246,1,192,1,126,1,050,952$, $879,798,731,693$. Elemental analysis: calcd. for $\mathrm{C}_{4} \mathrm{H}_{2} \mathrm{BrCl}_{2} \mathrm{NaO}_{2} \mathrm{~S}_{2}$, $19.29(\mathrm{C}), 0.81(\mathrm{H})$; found, $19.15(\mathrm{C}), 0.95(\mathrm{H})$.

$\mathrm{N}$-[(5-Bromothiophen-2-yl)sulfinyl]-2,4-dichlorobenzamide (Compound 7). Compound 6 (745 g, $3.00 \mathrm{mmol})$ was dissolved in a mixture of $\mathrm{Et}_{2} \mathrm{O}(13.0 \mathrm{~mL})$ and $\mathrm{H}_{2} \mathrm{O}(13.0 \mathrm{~mL})$, and concentrated $\mathrm{HCl}(0.5 \mathrm{~mL})$ was added. After the mixture had been stirred for $2 \mathrm{~h}$ at $40^{\circ} \mathrm{C}$, it was cooled to room temperature, and the organic layer was separated from the aqueous one. After evaporation of the solvent under reduced pressure, the sulfinic acid was obtained (653 $\mathrm{mg}, 3.0 \mathrm{mmol})$ and directly treated with $\mathrm{SOCl}_{2}(0.90 \mathrm{~mL}, 12.0$ $\mathrm{mmol})$ at $0^{\circ} \mathrm{C}$ under argon with dry dichloromethane $(12.0 \mathrm{~mL})$. After the mixture had been warmed to room temperature, it was left to stir for $3 \mathrm{~h}$, and the solvent was removed under reduced pressure. 2,4-Dichlorobenzamide was dissolved in dry tetrahydrofuran (THF; $12.0 \mathrm{~mL})$, and $n$-butyllithium $(1.6 \mathrm{M}, 1.80 \mathrm{~mL})$ was added at $-78^{\circ} \mathrm{C}$. After the mixture had been stirred for $20 \mathrm{~min}$, a solution of the chloride compound 5 in THF ( $4 \mathrm{~mL}$ ) was added dropwise to the mixture. The reaction mixture was stirred for $1 \mathrm{~h}$ at $-78^{\circ} \mathrm{C}$ and then left to warm up to room temperature. $\mathrm{H}_{2} \mathrm{O}(3 \mathrm{~mL})$ was added, and the mixture was extracted with ethyl acetate. After the solvent had been removed under reduced pressure, the mixture was directly subjected to column chromatography. Title compound 7 was isolated after FCC ( $n$-pentane:ethyl acetate $=4: 1$ ) as a white crystalline powder. The yield was $15 \%$. MP: $138-140^{\circ} \mathrm{C}$ (decomposition). ${ }^{1} \mathrm{H}-\mathrm{NMR}\left[600 \mathrm{MHz},\left(\mathrm{CD}_{3}\right)_{2} \mathrm{CO}\right]: \delta=10.75$ (bs, $\left.1 \mathrm{H}\right), 7.67$ $(\mathrm{d}, J=8.3 \mathrm{~Hz}, 1 \mathrm{H}), 7.62(\mathrm{~d}, J=1.9 \mathrm{~Hz}, 1 \mathrm{H}), 7.52(\mathrm{dd}, J=8.3,1.9$ $\mathrm{Hz}, 1 \mathrm{H}), 7.50(\mathrm{~d}, J=4.0 \mathrm{~Hz}, 1 \mathrm{H}), 7.33$ (d, $J=4.0 \mathrm{~Hz}, 1 \mathrm{H}) .{ }^{13} \mathrm{C}-\mathrm{NMR}$ [151 MHz, $\left.\left(\mathrm{CD}_{3}\right)_{2} \mathrm{CO}\right]: \delta=165.99,147.43,136.73,132.34,131.93$, $131.33,130.53,130.14,129.62,127.40,117.90$. MS (EI): $m / z=$ $399\left([\mathrm{M}]^{+}, 2\right), 209$ (35), 173 (100), 145 (30), 109 (27), 96 (17), 82 (37). MS (ESI): $m / z=421\left([\mathrm{M}+\mathrm{Na}]^{+}, 16\right)$. IR (ATR): $v=$ $3,122,2,935,2,661,2,325,2,180,2,088,1,905,1,671,1,580,1,396$, $1,240,1,083,966,883,803,746$. HRMS (ESI): $\mathrm{m} / z$ calcd. for $\mathrm{C}_{11} \mathrm{H}_{6} \mathrm{BrCl}_{2} \mathrm{NO}_{2} \mathrm{NaS}_{2}$, 419.8293 ; found, 419.8285 .

5-Bromo-N-(2,4-dichlorobenzoyl)thiophene-2-sulfonimidoyl Chloride (Compound 8). By use of N-chlorosuccinimide (NCS; Fig. 2, path d), compound 7 (200 $\mathrm{mg}, 0.50 \mathrm{mmol}$ ) was dissolved in acetonitrile $(1.70 \mathrm{~mL})$. After the mixture had been cooled to $0^{\circ} \mathrm{C}$, 
Fig. 2. Synthesis of sulfonimidamide compound 2. Reagents and conditions: (a) $\mathrm{Na}_{2} \mathrm{SO}_{3}$ (2.2 equiv.), $\mathrm{Na}_{2} \mathrm{CO}_{3}$ (1.8 equiv.), $\mathrm{H}_{2} \mathrm{O}, \mathrm{EtOH}$; (b) first, $\mathrm{HCl}, \mathrm{Et}_{2} \mathrm{O}, \mathrm{H}_{2} \mathrm{O}$, $40^{\circ} \mathrm{C}, 2 \mathrm{~h}$; second, $\mathrm{SOCl}_{2}$ (4.0 equiv.), dichloromethane; (c) compound 6 (1.0 equiv.), $n$-butyllithium (1.2 equiv.), THF, $-78^{\circ} \mathrm{C}$ to room temperature; (d) NCS $(2.0$ equiv.), $\mathrm{CH}_{3} \mathrm{CN}, 0^{\circ} \mathrm{C}, 1 \mathrm{~h}$; (e) $t$-butyl hypochlorite (1.5 equiv.), dichloromethane, $0^{\circ} \mathrm{C}, 2 \mathrm{~h}$; (f) $\mathrm{NH}_{3}$ (aq., conc.), $\mathrm{MeOH} / \mathrm{H}_{2} \mathrm{O}$ $(1: 1)$, room temperature, $2 \mathrm{~h}$, then $70^{\circ} \mathrm{C}$, $5 \mathrm{~h}$; (g) $\mathrm{NH}_{3}$ (g.), $15 \mathrm{~min}, \mathrm{THF},-78^{\circ} \mathrm{C}$ to room temperature; (h) $\mathrm{NH}_{3}$ in $\mathrm{MeOH}(7 \mathrm{M}$, 0.3 equiv), $\mathrm{MeOH}$, overnight; (i), hexamethyldisilazane (2.0 equiv.), $\mathrm{CH}_{3} \mathrm{CN}$, overnight.

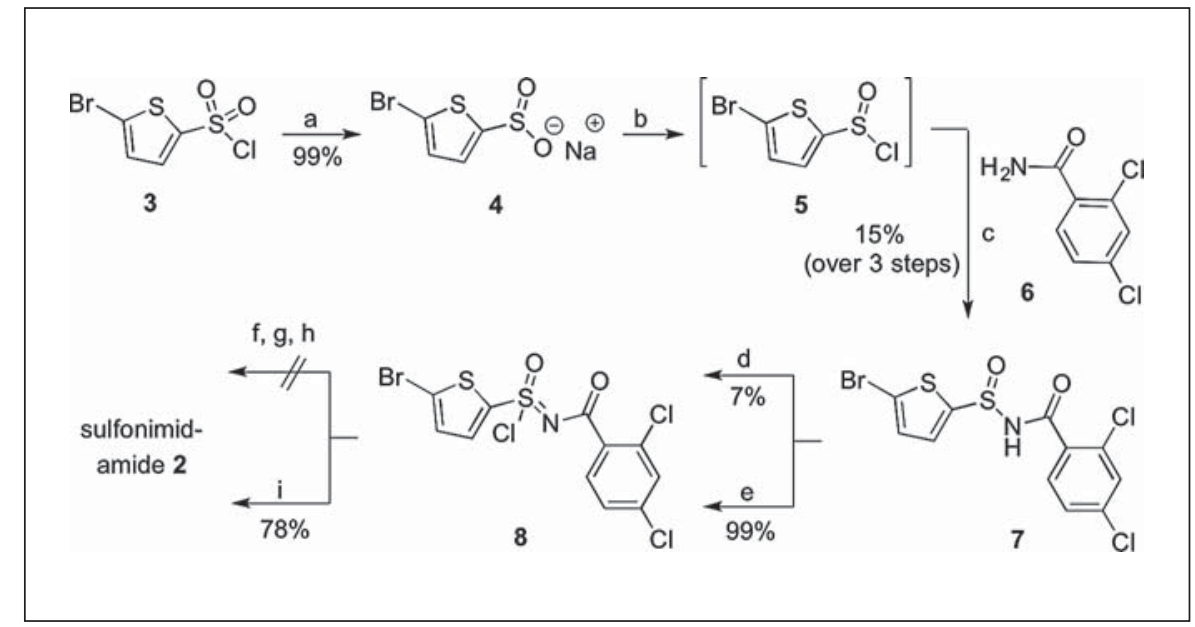

NCS (382 mg, $5.60 \mathrm{mmol}$ ) was added. The reaction mixture was left to reach room temperature and stirred for $1 \mathrm{~h}$ at room temperature. The mixture was directly suspended to the column, and compound 8 was isolated as white solid after purification by FCC ( $n$-pentane:ethyl acetate $=2: 1$ ). The yield was $7 \%$. By use of tertbutyl hypochloride (Fig. 2, path e), freshly prepared $t$-butyl hypochlorite [80] $(0.04 \mathrm{~mL}, 0.38 \mathrm{mmol})$ was added to an iced suspension of compound 7 (100 $\mathrm{mg}, 0.25 \mathrm{mmol})$. The solvent was removed under reduced pressure, and compound 8 was isolated as a white solid. The yield was $99 \%$. MP: $205-210^{\circ} \mathrm{C}$ (decomposition). ${ }^{1} \mathrm{H}-\mathrm{NMR}$ [600 MHz, $\left.\left(\mathrm{CD}_{3}\right)_{2} \mathrm{CO}\right]: \delta=8.15(\mathrm{~d}, J=4.3 \mathrm{~Hz}, 1 \mathrm{H}), 8.05$ $(\mathrm{d}, J=8.4 \mathrm{~Hz}, 1 \mathrm{H}), 7.67(\mathrm{~d}, J=2.1 \mathrm{~Hz}, 1 \mathrm{H}), 7.59(\mathrm{~d}, J=4.3 \mathrm{~Hz}, 1 \mathrm{H})$, $7.55(\mathrm{dd}, J=8.4,2.0 \mathrm{~Hz}, 1 \mathrm{H}) .{ }^{13} \mathrm{C}-\mathrm{NMR}\left[151 \mathrm{MHz},\left(\mathrm{CD}_{3}\right)_{2} \mathrm{CO}\right]$ : $\delta=167.85,141.11,138.06,137.14,134.14,133.12,132.71,131.62$, $130.77,127.40,126.18 . \mathrm{MS}(\mathrm{CI}): \mathrm{m} / z=434\left([\mathrm{M}+\mathrm{H}]^{+}, 4\right), 291(20)$, 257 (18), 211 (33), 190 (74), 172 (100), 156 65. MS (ESI): $m / z=456$ $\left([\mathrm{M}+\mathrm{Na}]^{+}, 100\right)$. IR (ATR): $v=3,346,3,178,3,082,2,924,2,855$, $2,654,2,299,2,097,2,021,1,670,1,585,1,469,1,402,1,365,1,325$, $1,259,1,233,1,201,1,091,1,045,963,804,765,689$. HRMS (ESI): $m / z$ calcd. for $\mathrm{C}_{11} \mathrm{H}_{5} \mathrm{O}_{2} \mathrm{NBrCl}_{3} \mathrm{NaS}_{2}, 453.7903$; found, 453.7909 .

\section{Biology}

Cell Culture

Melanoma cell lines were cultivated at $37^{\circ} \mathrm{C}$ in an atmosphere of $5 \% \mathrm{CO}_{2}$. SKMel23 cells were cultured with RPMI 1640 and $2 \mathrm{mM}$ L-glutamine (Invitrogen, Darmstadt, Germany), supplemented with $10 \%$ heat-inactivated fetal calf serum (Biochrom, Berlin, Germany) and $0.25 \mu \mathrm{g} / \mathrm{mL}$ puromycin (Invitrogen). A375 cells were grown in RPMI 1640 medium supplemented with 5\% fetal calf serum, $100 \mu \mathrm{g} / \mathrm{mL}$ streptomycin (Invitrogen) and $60 \mu \mathrm{g} /$ $\mathrm{mL}$ penicillin (Invitrogen).

\section{Proliferation Assay}

Cells $\left(5 \times 10^{3}\right)$ were seeded in 24 -well culture plates. After $18 \mathrm{~h}$ the cells were stimulated with various concentrations of the sulfonimidamide-based analog of tasisulam (compound 2) or tasisulam (compound 1). Control cells were treated with DMSO. All treatments were performed in triplicate. Proliferation was assayed 8, 24, 48 and $72 \mathrm{~h}$ after stimulation using the alamarBlue ${ }^{\circledR}$ cell proliferation assay (AbD Serotec, Düsseldorf, Germany) according to the manufacturer's protocol. Absorbance was measured using an Eon $^{\mathrm{TM}}$ (BioTek) microplate spectrophotometer at 570 and $600 \mathrm{~nm}$ (for reference).

\section{Results}

For the synthesis of sulfonimidamide compound 2 (Fig. 2), commercially available sulfonyl chloride compound 3 served as key component, and the corresponding sodium sulfinate compound 4 was generated in an excellent yield (99\%). Before the coupling with benzamide compound 6 , sodium salt compound 4 was converted to sulfinyl chloride compound 5, which was directly subjected to amide formation with the lithium salt of compond 6 to give $\mathrm{N}$-acyl sulfinamide compound 7 in $15 \%$ yield (over 3 steps). While chlorination of compound 7 with NCS gave N-acyl sulfonimidoyl chloride compound 8 in only $7 \%$ yield, the analogous halogenation with freshly prepared tert-butyl hypochloride led to target compound 8 essentially quantitatively. For finalizing the synthesis of compound 2, intermediate compound 8 had to be aminated. To our surprise, this last synthetic step proved challenging. All attempts to use ammonia (in aqueous, concentrated, diluted, or gaseous form) remained unsuccessful, and degradation of compound 8 occurred. Finally, hexamethyldisilazane proved to be a suitable $\mathrm{NH}_{2}$ equivalent [72], and in this manner, tasisulam analog 2 was obtained in $78 \%$ yield. The NMR spectroscopic data suggested the depicted (racemic) tautomeric structure for compound 2 . However, the alternative tautomer (with respect to the $\mathrm{N}=\mathrm{S}-\mathrm{NH}_{2}$ fragment) could not rigorously be excluded. The antiprolif- 


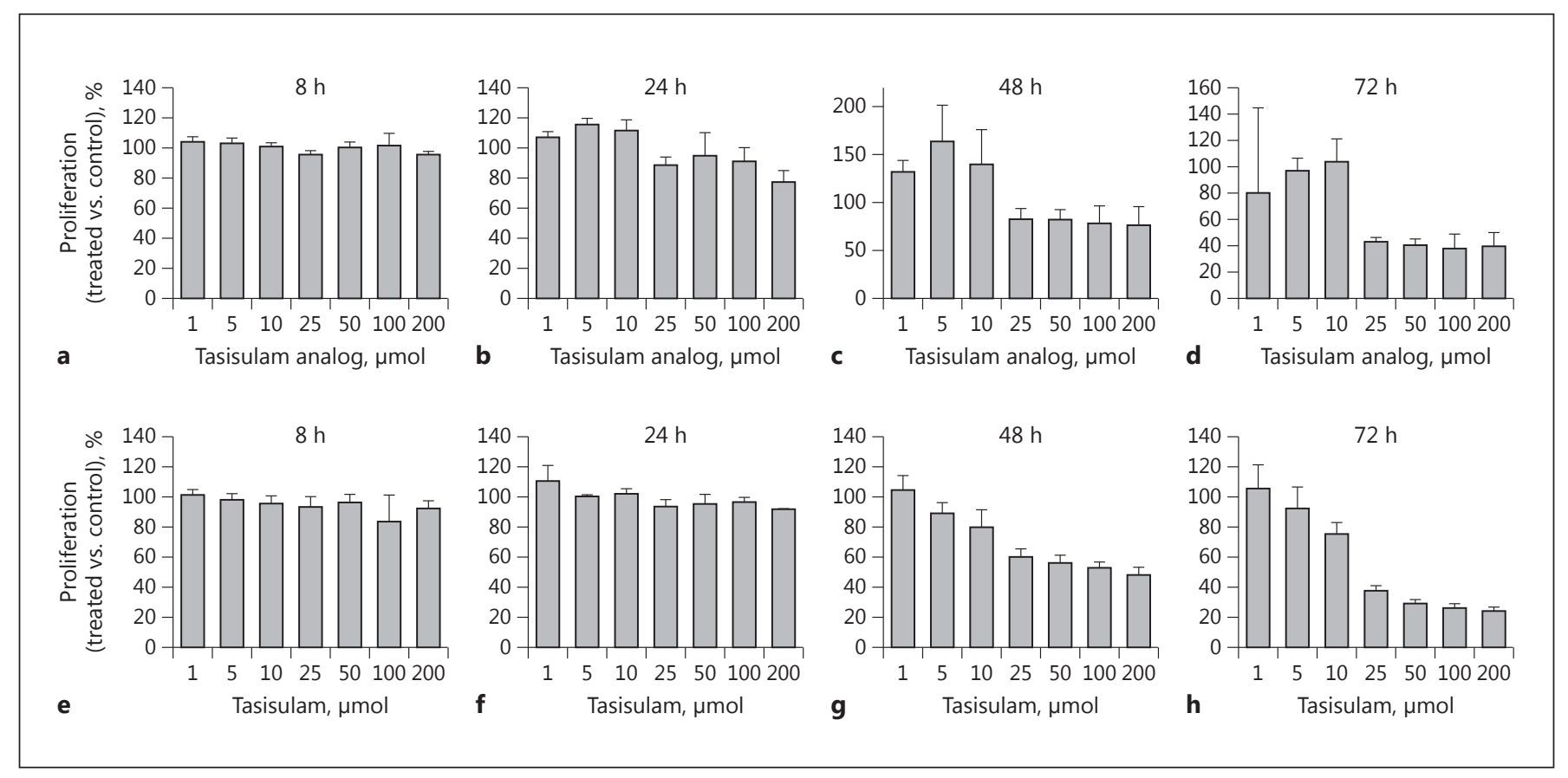

Fig. 3. Antiproliferative effect of the sulfonimidamide analog of tasisulam (compound 2, a-d) and the original compound 1 (tasisulam, e-h) in the melanoma cell line A375.

erative properties of the sulfonimidamide-based analog of tasisulam (compound 2) were evaluated in comparison to the original compound 1 (tasisulam) by performing a cell proliferation assay in the 2 melanoma cell lines SKMel23 and A375. The results revealed that analog 2 had inhibitory effects on the proliferation comparable to tasisulam (compound 1) in both investigated cell lines. As shown in Figures 3 and $4 \mathrm{a}, \mathrm{b}, \mathrm{e}$, and $\mathrm{f}$, both analog 2 and the original substance 1 had essentially no effect on cell proliferation 8 and $24 \mathrm{~h}$ after treatment of the melanoma cell lines A375 and SKMel23. Also 48 and $72 \mathrm{~h}$ after treatment, both substances had no effect on cell proliferation up to a concentration of $10 \mu \mathrm{mol}$ in the melanoma cell line SKMel23 but exhibited dose-dependent effects in the range of 25-200 $\mu \mathrm{mol}$ (Fig. 4c, d, g, and $h$ ).

Seventy-two hours after stimulation of SKMel23 cells with $200 \mu \mathrm{mol}$ of the sulfonimidamide-based tasisulam analog (compound 2), cell proliferation was strongly reduced by $76 \%$ in comparison to DMSO-treated control cells (Fig. 4d). Inhibition of cell proliferation in A375 cells exposed to tasisulam analog $2(25-200 \mu \mathrm{mol})$ was lower than in cells exposed to tasisulam (compound 1) $48 \mathrm{~h}$ after stimulation (Fig. 3c, g). Further evaluation revealed that $72 \mathrm{~h}$ after stimulation tasisulam analog 2 as well as the original compound 1 inhibited A375 cell proliferation highly efficiently. In comparison to DMSO-treated control cells, compound 2 reduced cell proliferation down to $40 \%$ and tasisulam (compound 1 ) even down to $25 \%$ (Fig. 3c, h).

\section{Discussion}

Tasisulam is a promising drug which is used as an antiproliferative agent in patients with metastatic melanoma and other solid tumors [10, 13, 14-16]. A randomized, open-label clinical trial of tasisulam sodium versus paclitaxel as second-line treatment in patients with metastatic melanoma has recently been stopped early because of safety issues in the tasisulam arm. Although it was considered to be unlikely that tasisulam was superior to prior chemotherapies, the importance of pharmacokinetic monitoring of compounds with complex dosing was underscored [43].

Especially in the era before immuno- and targeted therapy, chemotherapy has long been the mainstay in the treatment of advanced melanoma particularly with compounds such as fotemustine, dacarbazine, temozolomide, and platinum-based agents. Much effort has been made 


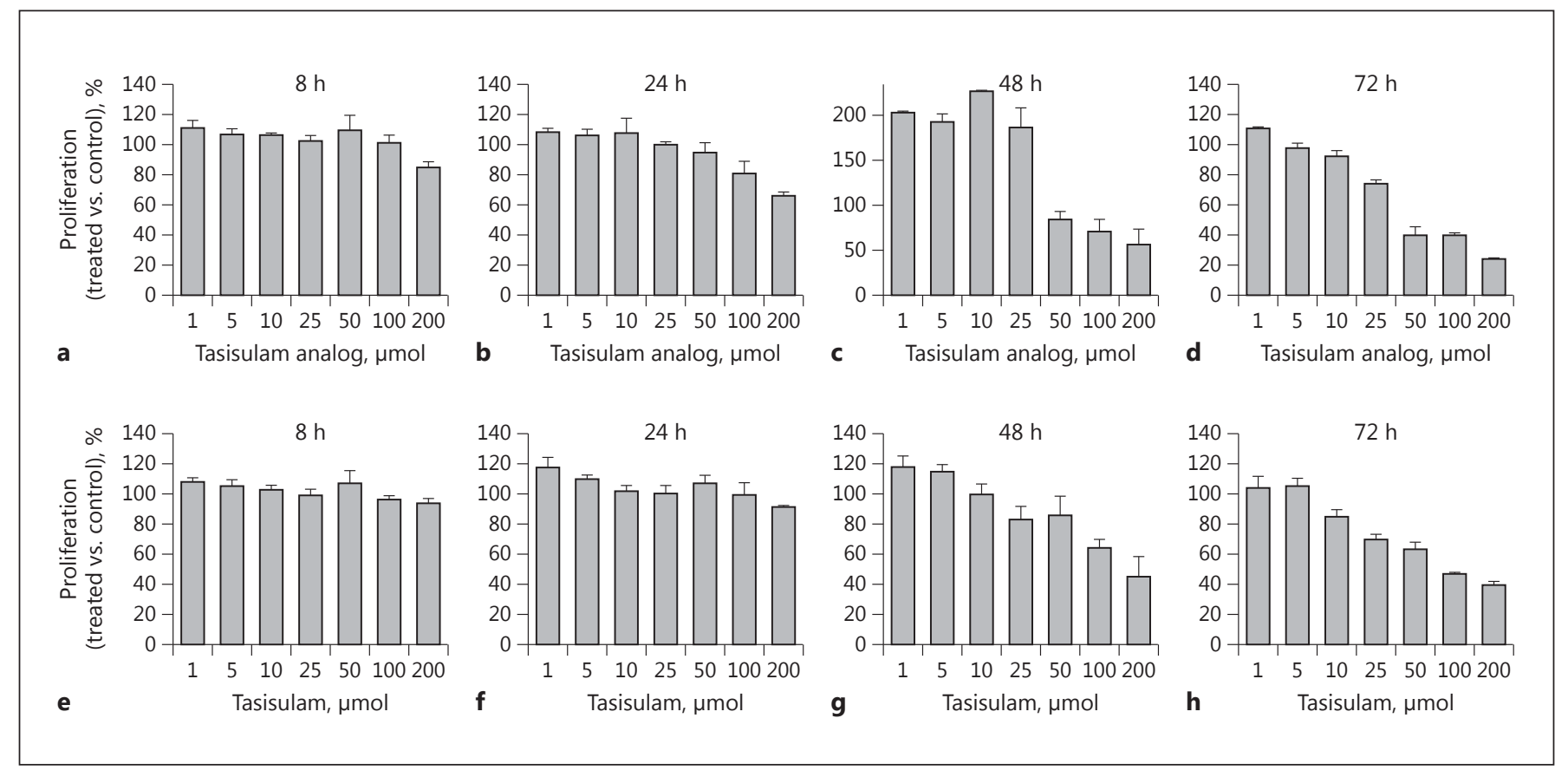

Fig. 4. Antiproliferative effect of the sulfonimidamide analog of tasisulam (compound 2, a-d) and the original compound 1 (tasisulam, e-h) in the melanoma cell line SKMel23.

to increase response rates and to prolong survival by combined treatment modalities. However, until now there have been no defined and generally accepted standards of systemic treatment in metastatic melanoma [81, 82].

Melanoma is a common type of skin cancer with a high propensity to metastasize. Tyrosine kinase inhibitors targeting the mitogen-activated protein kinase pathway and immune checkpoint blockade have recently revolutionized the management of unresectable and metastatic disease. However, acquired resistance and primary nonresponse to therapy require novel treatment strategies and combinations [7]. The double-blind, randomized phase 3 study COMBI-d compared dabrafenib and trametinib to dabrafenib alone. The objective RR lay at $67 \%$ for the combination and at $51 \%$ for the monotherapy cohort [83]. In addition to objective clinical benefits such as delayed progression or longer overall survival, patients receiving the combination showed a better health-related quality of life along with significant functional and pain improvements compared with patients receiving monotherapy with dabrafenib. While these targeted therapies can be only applied in approximately $50 \%$ of melanoma patients, immunotherapies can be a therapeutic option independent of the mutational status.
The antibody ipilimumab is directed against CTLA-4 and administered intravenously for 4 cycles at 3-weekly intervals, in contrast to the PD- 1 inhibitors, which are applied as continuous therapy. These monoclonal antibodies are also called immune checkpoint inhibitors and are crucial in controlling immune responses. Data from several phase 2 and phase 3 trials have recently been collected and analyzed, revealing a median survival time of 11.4 months for ipilimumab monotherapy [84]. According to the studies that have been published thus far, the response rates of ipilimumab as monotherapy are lower than those with PD-1 inhibitors, and the rate of adverse events is higher, which makes ipilimumab uncertain as monotherapy in melanoma in the future.

The combination of a CTLA- 4 and a PD- 1 inhibitor seems to be superior to the monotherapies, especially in patients with PD-L1 negative tumors [85-87]. Data have already been published and revealed a response rate of $58 \%$ for the combination, $44 \%$ for nivolumab alone, and $19 \%$ for ipilimumab alone [7]. However, the high antitumor efficacy was accompanied by an elevated frequency of severe immune-related adverse events. In the combination cohort, nearly all patients experienced at least 1 side effect, while $57 \%$ showed an event of grade 3 or 4 . In $39 \%$ of all patients the combination therapy had to be 
stopped due to side effects such as diarrhea with colitis or hepatitis with elevated liver enzymes. Pembrolizumab and nivolumab show higher response rates compared to ipilimumab and fewer severe immune-related adverse events [7]. Recent advances in targeted and immunotherapy have significantly improved the patient outcome. However, there is still a substantial number of patients with primary or acquired resistance in need of innovative treatment modalities and combination therapies.

As for chemotherapeutic agents, dacarbazine is the most widely used single-agent chemotherapy for metastatic melanoma and has shown low response rates of $6-8 \%$ and a median overall survival of 6-12 months across largescale group trials with follow-up times over 22 months [88-90]. Additionally, in a retrospective chart analysis of metastatic melanoma patients treated with various secondline therapies, the response rate was only $2 \%$ [91].

Fotemustine has also been investigated as chemotherapy in advanced melanoma treatment [92]. In a retrospective study it was the second most common agent used as first-line systemic treatment in France and Italy, despite modest clinical activity [93].

Paclitaxel activity in patients with metastatic melanoma showed RRs of $15 \%$, with several patients reported to achieve a complete response [94-96]. A study with singleagent paclitaxel in second-line treatment showed an RR of $5 \%$, without an observation of complete response. Previous studies have suggested that paclitaxel in combination with carboplatin may have a slight additional benefit in the second-line treatment of patients with metastatic melanoma but may also be associated with greater hematological toxicity [97, 98].

Tasisulam is of high interest because of its unique dual antitumor mechanism of action, involving antiangiogenesis and mitotic inhibition [11]. Investigation of the unexpectedly high rate of hematological toxicity revealed a subset of patients with low tasisulam clearance, leading to drug accumulation and high albumin-corrected exposure in cycle 2 [79]. Because of high-affinity albumin binding and rapid, extensive metabolism of free tasisulam in vivo, preclinical studies had failed to identify a clearance mechanism for unbound tasisulam, which is the biologically active form. Tasisulam shows biexponential disposition with a median terminal elimination half-life of approximately 11 days. Therefore, given the extensive albumin binding of tasisulam and its long terminal half-life, a loading dose in cycle 1 followed by a lower chronic dose in subsequent cycles were necessary to decrease the risk of a progressive rise in drug concentrations in later cycles and to reduce the risk of saturating albumin binding. Unbound tasisulam clear- ance was found to be lower than the population mean in the majority of the patients ( 27 of 28 ) who experienced grade $4 / 5$ hematological toxicities. Possible explanations for the lower tasisulam clearance also include CYP2C19 polymorphisms and the use of CYP2C19-inhibiting proton pump inhibitors, which is consistent with subsequent findings that it may be metabolized by CYP2C19. However, none of these factors explain the vast majority of observed grade $4 / 5$ cases of hematological toxicity.

Therefore, we decided to prepare a sulfonimidamide analog of tasisulam in the intention to reduce the toxicity imbalance. Initial in vitro testing revealed similar antiproliferative properties on the melanoma cell lines SKMel23 and A375 tested compared to the original compound. Further preclinical studies will be needed to evaluate the renal clearance rate and hematological toxicity of this sulfonimidamide analog in order to find out whether this compound could be an alternative treatment with less hematological side effects for patients with metastatic melanoma and other solid tumors to improve safety and efficacy of the therapy.

\section{Note Added in Proof}

At the proof stage of the manuscript an important overview on medical and agrochemical applications of sulfonimidamides appeared [99].

\section{Acknowledgments}

We thank Dr. I. Schiffers for helpful discussions and C. Dannenberg and H. Baars (all Institute of Organic Chemistry, RWTH Aachen University) for proofreading early versions of the manuscript.

\section{Statement of Ethics}

Neither human participants nor human cell material were used.

\section{Disclosure Statement}

All authors have declared no conflict of interest. 


\section{References}

1 Miller AJ, Mihm MC Jr: Melanoma. N Engl J Med 2006;355:51-65.

2 Jemal A, Siegel R, Xu J, Ward E: Cancer statistics, 2010. CA Cancer J Clin 2010;60:277-300.

3 Flaherty KT, Puzanov I, Kim KB, et al: Inhibition of mutated, activated BRAF in metastatic melanoma. N Engl J Med 2010;363:809-819.

4 Chapman PB, Hauschild A, Robert C, et al; BRIM-3 Study Group: Improved survival with vemurafenib in melanoma with BRAF V600E mutation. N Engl J Med 2011;364: 2507-2516.

5 Hu-Lieskovan S, Mok S, Homet Moreno B, et al: Improved antitumor activity of immunotherapy with BRAF and MEK inhibitors in BRAF (V600E) melanoma. Sci Transl Med 2015;7:279ra41.

6 Zito CR, Kluger HM: Immunotherapy for metastatic melanoma. J Cell Biochem 2012; 113:725-734.

7 Heppt MV, Dietrich C, Graf SA, et al: The Systemic Management of Advanced Melanoma in 2016. Oncol Res Treat 2016;39:635-642.

8 Schadendorf D, Fisher DE, Garbe C, et al: Melanoma. Nat Rev Dis Primers 2015;1: 15003.

9 Hodi FS, Chesney J, Pavlick AC, et al: Combined nivolumab and ipilimumab versus ipilimumab alone in patients with advanced melanoma: 2-year overall survival outcomes in a multicentre, randomised, controlled, phase 2 trial. Lancet Oncol 2016;17:15581568.

10 Kirkwood JM, Gonzalez R, Reintgen D, et al: A phase 2 study of tasisulam sodium (LY573636 sodium) as second-line treatment for patients with unresectable or metastatic melanoma. Cancer 2011;117:4732-4739.

11 Meier T, Uhlik M, Chintharlapalli S, Dowless M, Van Horn R, Stewart J, Blosser W, Cook J, Young, D, Ye X, Evans G, Credille K, Ballard D, Huber L, Capen A, Chedid M, Ilaria R, Smith MC, Stancato L: Tasisulam sodium, an antitumor agent that inhibits mitotic progression and induces vascular normalization. Mol Cancer Ther 2011;10:2168-2178.

12 Paull KD, Shoemaker RH, Hodes L, et al: Display and analysis of patterns of differential activity of drugs against human tumor cell lines: development of mean graph and COMPARE algorithm. J Natl Cancer Inst 1989;81:10881092.

13 Scagliotti GV, Ilaria R Jr, Novello S, von Pawel J, Fischer JR, Ermisch S, de Alwis DP, Andrews J, Reck M, Crino L, Eschbach C, Manegold C: Tasisulam sodium (LY573636 sodium) as third-line treatment in patients with unresectable, metastatic non-small-cell lung cancer: a phase-II study. J Thorac Oncol 2012; 7:1053-1057.
14 Gordon M, McMeekin S, Temkin S, Tew W, Yapp S, Scambia G, Streltsova O, Kaiser C, Ilaria R, Look K: A phase II, single-arm study of tasisulam sodium (LY573636 sodium) as 2nd-4th line therapy for platinum-resistant ovarian cancer. AACR-NCI-EORTC international conference: molecular targets and cancer therapeutics. Mol Cancer Ther 2009;8(12 suppl):B197.

15 Fujiwara Y, Ando Y, Mukohara T, Kiyota N, Chayahara N, Mitsuma A, Inada-Inoue M, Sawaki M, Ilaria R Jr, Kellie Turner P, Funai J, Maeda K, Minami H: A phase I study of tasisulam sodium using an albumin-tailored dose in Japanese patients with advanced solid tumors. Cancer Chemother Pharmacol 2013; 71:991-998.

16 Ryan CW, Matias C, Agulnik M, Lopez-Pousa A, Williams C, de Alwis DP, Kaiser C, Miller MA, Ermisch S, Ilaria R Jr, Keohan ML: A phase II study of tasisulam sodium (LY573636 sodium) as second-line or third-line treatment for patients with unresectable or metastatic soft tissue sarcoma. Invest New Drugs 2013;31:145-151.

17 Meanwell NA: Synopsis of some recent tactical application of bioisosteres in drug design. J Med Chem 2011;54:2529-2591.

18 Bizet V, Hendriks CMM, Bolm C: Sulfur imidations: access to sulfimides and sulfoximines. Chem Soc Rev 2015;44:3378-3390.

19 Park SJ, Baars H, Mersmann S, Buschmann H, Baron JM, Amann PM, Czaja K, Hollert H, Bluhm K, Redelstein R, Bolm C: N-cyano sulfoximines: COX inhibition, anticancer activity, cellular toxicity, and mutagenicity. Chem Med Chem 2013;8:217-220.

20 Chen XY, Park SJ, Buschmann H, De Rosa M, Bolm C: Syntheses and biological activities of sulfoximine-based acyclic triaryl olefins. Bioorg Med Chem Lett 2012;22:4307-4309.

21 Park SJ, Buschmann H, Bolm C: Bioactive sulfoximines: syntheses and properties of Vioxx ${ }^{\circledR}$ analogs. Bioorg Med Chem Lett 2011; 21:4888-4890.

22 Hendriks CMM, Nürnberg P, Bolm C: Zolimidine analogues: the synthesis of imidazo[1, 2-a]pyridine-based sulfilimines and sulfoximines. Synthesis 2015;47:1190-1194.

23 Chen XY, Buschmann H, Bolm C: Sulfoximine- and sulfilimine-based DAPSON analogues. Syntheses and bioactivities. Synlett 2012;23:2808-2810.

24 Steinkamp A-D, Seling N, Lee S, Boedtkjer E, Bolm C: Synthesis of N-cyano-substituted sulfilimine and sulfoximine derivatives of S0859 and their biological evaluation as sodium bicarbonate co-transport inhibitors. Med Chem Comm 2015;6:2163-2169.
25 Lücking U, Jautelat R, Krüger M, Brumby T, Lienau P, Schäfer M, Briem H, Schulze J, Hillisch A, Reichel A, Wengner AM, Siemeister G: The lab oddity prevails: discovery of pan-CDK inhibitor (R)-S-cyclopropyl-S-(4$\{[4-\{[(1 \mathrm{R}, 2 \mathrm{R})$-2-hydroxy-1-methylpropyl $]$ oxy\}-5-(trifluoromethyl)pyrimidin-2-yl] amino\}phenyl)sulfoximide (BAY1000394) for the treatment of cancer. Chem Med Chem 2013;8:1067-1085

26 Foote KM, Nissink JWM, Turner P: WO2011/154737 A1. AstraZeneca.

27 Lücking U: Sulfoximines: a neglected opportunity in medicinal chemistry. Angew Chem Int Ed 2013;52:9399-9408.

28 Goldberg FW, Kettle JG, Xiong J, Lin D: General synthetic strategies towards $\mathrm{N}$-alkyl sulfoximine building blocks for medicinal chemistry and the use of dimethylsulfoximine as a versatile precursor. Tetrahedron 2014;70: 6613-6622.

29 Frings M, Bolm C, Blum A, Gnamm C: Sulfoximines from a medicinal chemist's perspective: physicochemical and in vitro parameters relevant for drug discovery. Eur J Med Chem. http://dx.doi.org/10.1016/j.ejmech.2016. 09.091

30 Seydel JK: Sulfonamides, structure-activity relationship, and mode of action. Structural problems of the antibacterial action of 4-aminobenzoic acid (PABA) antagonists. J Pharm Sci 1968;57:1455-1478.

31 Ohmachi Y, Toriumi W, Takashima K, Doi K: Systemic histopathology of rats treated with 6-sulfanilamidoindazole, a novel arthritogenic sulfonamide. Toxicol Pathol 1998;26:62270 .

32 Schenone S, Brullo C, Bruno O, Bondavalli F, Ranise A, Filippelli W, Rinaldi B, Capuano A, Falcone, G: New 1,3,4-thiadiazole derivatives endowed with analgesic and anti-inflammatory activities. Bioorg Med Chem 2006; 14: 1698-1705.

33 Kadi AA, El-Brollosy NR, Al-Deeb O, Habib EE, Ibrahim TM, El-Emam AA: Synthesis, antimicrobial, and anti-inflammatory activities of novel 2-(1-adamantyl)-5-substituted 1,3,4oxadiazoles and 2-(1-adamantylamino)5-substituted 1,3,4-thiadiazoles. Eur J Med Chem 2007;42:235-242.

34 Blobaum AL, Marnett LJ: Structural and functional basis of cyclooxygenase inhibition. J Med Chem 2007;50:1425-1441.

35 Bentley R: Different roads to discovery: prontosil (hence sulfa drugs) and penicillin (hence $\beta$-lactams). J Ind Microbiol Biotechnol 2009; 36:775-786.

36 Ghorab MM, Ragab FA, Heiba HI, El-Hazek RM: Anticancer and radio-sensitizing evaluation of some new thiazolopyrane and thiazolopyranopyrimidine derivatives bearing a sulfonamide moiety. Eur J Med Chem 2011;46: $5120-5126$ 
37 Ma Y, McCarty SK, Kapuriya NP, Brendel VJ, Wang C, Zhang X, Jarjoura D, Saji M, Chen CS, Ringel MD: Development of p21 activated kinase-targeted multikinase inhibitors that inhibit thyroid cancer cell migration. J Clin Endocrinol Metab 2013;98:E1314-E1322.

38 Ali I, Wani WA, Saleem K, Hsieh MF: Anticancer metallodrugs of glutamic acid sulphonamides: in silico, DNA binding, hemolysis and anticancer studies. RSC Adv 2014;4: 29629-29641.

39 Vullo D, Del Prete S, Fisher GM, Andrews KT, Poulsen SA, Capasso C, Supuran CT: Sulfonamide inhibition studies of the $\eta$-class carbonic anhydrase from the malaria pathogen Plasmodium falciparum. Bioorg Med Chem 2015;23:526-531.

40 Ghorab MM, Ragab FA, Heiba HI, El-Gazzar MG, Zahran SS: Synthesis, anticancer and radiosensitizing evaluation of some novel sulfonamide derivatives. Eur J Med Chem 2015 92:682-692.

41 Lobb KL, Hipskind PA, Aikins JA, Alvarez E, Cheung YY, Considine EL, De Dios A, Durst GL, Ferritto R, Grossman CS, Giera DD, Hollister BA, Huang Z, Iversen PW, Law KL, Li T, Lin HS, Lopez B, Lopez JE, Cabrejas LMM, McCann DJ, Molero V, Reilly JE, Richett ME Shih C, Teicher B, Wikel JH, White WT, Mader MM: Acyl sulfonamide anti-proliferatives: benzene substituent structure-activity relationships for a novel class of antitumor agents. J Med Chem 2004;47:5367-5380.

42 Mader MM, Shih C, Considine E, Dios AD Grossman CS, Hipskind PA, Lin HS, Lobb KL, Lopez B, Lopez JE, Cabrejas LMM, Richett ME, White WT, Cheung YY, Huang Z, Reilly JE, Dinn SR: Acyl sulfonamide antiproliferatives. 2. Activity of heterocyclic sulfonamide derivatives. Bioorg Med Chem Lett 2005; 15:617-620.

43 Sehgelmeble F, Janson J, Ray C, Rosqvist S, Gustavsson S, Nilsson LI, Minidis A, Holenz J, Rotticci D, Lundkvist J, Arvidsson PI: Sulfonimidamides as sulfonamides bioisosteres: rational evaluation through synthetic, in vitro, and in vivo studies with $\gamma$-secretase inhibitors. Chem Med Chem 2012;7:396-399.

44 Pemberton N, Graden H, Evertsson E, Bratt E, Lepistö M, Johannesson P, Svensson PH: Synthesis and functionalization of cyclic sulfonimidamides: a novel chiral heterocyclic carboxylic acid bioisostere. ACS Med Chem Lett 2012;3:574-578.

45 Borhade SR, Svensson R, Brandt P, Artursson P, Arvidsson PI, Sandström A: Preclinical characterization of acyl sulfonimidamides: potential carboxylic acid bioisosteres with tunable properties. Chem Med Chem 2015; 10:455-460

46 Ballatore C, Huryn DM, Smith AB: Carboxylic acid (bio)isosteres in drug design. Chem Med Chem 2013;8:385-395.
47 Gnamm C, Jeanguenat A, Dutton AC, Grimm C, Kloer DP, Crossthwaite AJ: Novel diamide insecticides: sulfoximines, sulfonimidamides and other new sulfonimidoyl derivatives. Bioorg Med Chem Lett 2012;22:3800-3806.

48 Sen I, Kloer DP, Hall RG, Pal S: Synthesis of six-membered cyclic sulfonimidamides. Synthesis 2013;45:3018-3028.

49 Paulini R, Breuninger D, von Deyn W, Nastlaans HMM, Beyer C, Anspaugh DD, Oloumi-Sadeghi H: WO 2009/156336 A1. BASF.

50 Levchenko ES, Sheinkman IE, Kirsanov AV. Phenylamides of N-dianilinophosphinylareniminosulfonic acids. Zh Obshch Khim 1960; 30:1941-1946.

51 Levchenko ES, Derkach NY, Kirsanov, AV Amides of $\mathrm{N}_{2}$-arylsulfonylaryliminosulfonic acids. Zh Obshch Khim 1962;32:1208-1212.

52 Johnson CR, Lavergne O: Preparation of free sulfoximines by treatment of $\mathrm{N}$-tosylsulfoximines with sodium anthracenide. J Org Chem 1989:54;986-988

53 Johnson CR, Lavergne OM: Alkylation of sulfoximine and related compounds at the imino nitrogen under phase-transfer conditions. J Org Chem 1993;58:1922-1923.

54 Levchenko ES, Markovskii LN, Shermolovich YG: Chemistry of sulfonimide acid derivatives. Russ J Org Chem 2000;36:143-157.

55 Rashatasakhan P, Harmata M: Chiral nitrenes from sulfonimidamides. Chemtracts Org Chem 2006;19:143-151.

56 Funes Maldonado M, Sehgelmeble F, Bjarnemark F, Svensson M, Åhman J, Arvidsson PI: Synthesis and arylation of unprotected sulfonimidamides. Tetrahedron 2012;68:74567462 .

57 Borhade SR, Sandström A, Arvidsson PI: Synthesis of novel aryl and heteroaryl acyl sulfonimidamides via $\mathrm{Pd}$-catalyzed carbonylation using a nongaseous precursor. Org Lett 2013; 15:1056-1059.

58 Wakchaure PB, Borhade SR, Sandström A, Arvidsson PI: Synthesis of vinyl- and aryl-acyl sulfonimidamides through Pd-catalyzed carbonylation using $\mathrm{Mo}(\mathrm{CO})_{6}$ as ex situ $\mathrm{CO}$ source. Eur J Org Chem 2015;213-219.

59 Nandi GC, Kota SR, Naicker T, Govender T, Kruger HG, Arvidsson PI: $\mathrm{Cu}(\mathrm{OAc})_{2}$-catalysed oxidative dual $\mathrm{C}-\mathrm{H} / \mathrm{N}-\mathrm{H}$ activation of terminal alkynes and $\mathrm{N}$-deprotected sulfonimidamides: an easy access to $\mathrm{N}$-alkynylated sulfonimidamides. Eur J Org Chem 2015; 2861-2867.

60 Battula SRK, Subbareddy GV, Chakravarthy IE: A mild and efficient copper-catalyzed Narylation of unprotected sulfonimidamides using boronic acids. Tetrahedron Lett 2014; 55:517-520.

61 Leca D, Toussaint A, Mareau C, Fensterbank L, Lacôte E, Malacria M: Efficient copper-mediated reactions of nitrenes derived from sulfonimidamides. Org Lett 2004;6:3573-3575.
62 Azzaro S, Fensterbank L, Lacôte E, Malacria M: Probing the amino-end reactivity of sulfonimidamides. Synlett 2008;2253-2256.

63 Azzaro S, Murr MDE, Fensterbank L, Lacôte E, Malacria M: Copper-catalyzed $\mathrm{N}$-arylation of sulfonimidamides. Synlett 2011;849-851.

64 Di Chenna PH, Robert-Peillard F, Dauban P, Dodd RH: Sulfonimidamides: efficient chiral iminoiodane precursors for diastereoselective copper-catalyzed aziridination of olefins. Org Lett 2004;6:4503-4505.

65 Robert-Peillard F, Di Chenna PH, Liang C, Lescot C, Collet F, Dodd RH, Dauban P: Catalytic stereoselective alkene aziridination with sulfonimidamides. Tetrahedron Asymmetry 2010;21:1447-1457.

66 Liang C, Robert-Peillard F, Fruit C, Müller P, Dodd RH, Dauban P: Efficient diastereoselective intermolecular rhodium-catalyzed $\mathrm{C}-\mathrm{H}$ amination. Angew Chem Int Ed 2006;45: 4641-4644.

67 Liang C, Collet F, Robert-Peillard F, Müller P, Dodd RH, Dauban P: Toward a synthetically useful stereoselective $\mathrm{C}-\mathrm{H}$ amination of hydrocarbons. J Am Chem Soc 2008;130;343350

68 Worch C, Bolm C: Use of prolyl sulfonimidamides in solvent-free organocatalytic asymmetric aldol reactions. Synlett 2009; 2425-2428

69 Steurer M, Bolm C: Synthesis of amino-functionalized sulfonimidamides and their application in the enantioselective Henry reaction. J Org Chem 2010;75:301-3310.

70 Patureau FW, Worch C, Siegler MA, Spek AL, Bolm C, Reek JNH: SIAPhos: phosphorylated sulfonimidamides and their use in iridiumcatalyzed asymmetric hydrogenations of sterically hindered cyclic enamides. Adv Synth Catal 2012;35:59-64.

71 Worch C, Bolm C: Efficient synthesis of sulfonimidoylguanidines by coupling of sulfonimidamides with uronium reagents. Synthesis 2007;1355-1358.

72 García Mancheño O, Bolm C: Synthesis of sulfonimidamides from sulfinamides by oxidation with N-chlorosuccinimide. Beilstein J Org Chem 2007;3:1-5.

73 Worch C, Bolm C: Copper-mediated crosscoupling reaction of $\mathrm{N}$-protected sulfonimidamides and aryl halides. Synthesis 2008; 739-742.

74 Worch C, Atodiresei I, Raabe G, Bolm C: Synthesis of enantiopure sulfonimidamides and elucidation of their absolute configuration by comparison of measured and calculated $\mathrm{CD}$ spectra and X-ray crystal structure determination. Chem Eur J 2010;16:677-683.

75 Wen J, Cheng H, Dong S, Bolm C: CopperCatalyzed S-C/S-N Bond Interconversions. Chem Eur J 2016;22:5547-5550. 
76 Jotte RM, Von Hoff DD, Braiteh F, Becerra CR, Richards DA, Smith DA, Garbo L, Stephenson J, Conkling PR, Robert-Vizcarrondo F, Chen J, Turner PK, Chow KH, Tai DF, Ilaria R: An innovative, multi-arm, complete phase $1 \mathrm{~b}$ study of the novel anti-cancer agent tasisulam in patients with advanced solid tumors. Invest New Drugs 2014;33:148-158.

77 Yates MH, Kallman NJ, Ley CP, Wei JN: Development of an acyl sulfonamide anti-proliferative agent, LY573636 $\cdot \mathrm{Na}^{+}$. Org Process Res Dev 2009;13:255-262.

78 White TD, Berglund KD, Groh JM, Johnson MD, Miller RD, Yates MH: Development of a continuous Schotten-Baumann route to an acyl sulfonamide. Org Process Res Dev 2012; 16:939-957.

79 Hamid O, Ilaria R, Garbe C, Wolter P, Maio M, Hutson TE, Arance A, Lorigan P, Lee J, Hauschild A, Mohr P, Hahka-Kemppinen M, Kaiser C, Turner PK, Conti I, Grob JJ: A randomized, open-label clinical trial of tasisulam sodium versus paclitaxel as second-line treatment in patients with metastatic melanoma. Cancer 2014;120:2016-2024.

80 Mintz MJ, Walling C: $t$-Butyl hypochlorite. Org Synth 1969;49:9-12.

81 Guerry D, Schuchter LM: Disseminated melanoma: is there a new standard therapy? $\mathrm{N}$ Engl J Med 1992;327:560-561.

82 Schadendorf D: Is there a standard for the palliative treatment of melanoma? Onkologie 2002;25:74-76.

83 Long GV, Stroyakovskiy D, Gogas H, et al: Combined BRAF and MEK inhibition versus BRAF inhibition alone in melanoma. $\mathrm{N}$ Engl J Med 2014;371:1877-1888.

84 Schadendorf D, Hodi FS, Robert C, et al: Pooled analysis of long-term survival data from phase II and phase III trials of ipilimumab in unresectable or metastatic melanoma. J Clin Oncol 2015;33:1889-1894.
85 Wolchok JD, Kluger H, Callahan MK, et al: Nivolumab plus ipilimumab in advanced melanoma. N Engl J Med 2013;369:122-133.

86 Postow MA, Chesney J, Pavlick AC, et al: Nivolumab and ipilimumab versus ipilimumab in untreated melanoma. N Engl J Med 2015;372:2006-2017.

87 Franklin C, Livingstone E, Roesch A, et al: Immunotherapy in melanoma: recent advances and future directions. Eur J Surg Oncol 2016, Epub ahead of print.

88 Avril MF, Aamdal S, Grob JJ, Hauschild A, Mohr P, Bonerandi JJ, et al: Fotemustine compared with dacarbazine in patients with disseminated malignant melanoma: a phase III study. J Clin Oncol 2004;22:1118-1125.

89 Bedikian AY, Millward M, Pehamberger H, Conry R, Gore M, Trefzer U, et al; Oblimersen Melanoma Study Group: Bcl-2 antisense (oblimersen sodium) plus dacarbazine in patients with advanced melanoma: the Oblimersen Melanoma Study Group. J Clin Oncol 2006;24:4738-4745.

90 Schadendorf D, Ugurel S, Schuler-Thurner B, Nestle FO, Enk A, Bröcker EB, et al; DC Study Group of the DeCOG: Dacarbazine (DTIC) versus vaccination with autologous peptidepulsed dendritic cells (DC) in first-line treatment of patients with metastatic melanoma: a randomized phase III trial of the DC study group of the DeCOG. Ann Oncol 2006;17: 563-570.

91 Walker MS, Reyes C, Kerr J, Satram-Hoang S Stepanski EJ: Treatment patterns and outcomes among patients with metastatic melanoma treated in community practice. Int Dermatol 2014;53:499-506.
92 Garbe C, Eigentler TK, Keilholz U, Hauschild A, Kirkwood JM: Systematic review of medical treatment in melanoma: current status and future prospects. Oncologist 2011;16:5-24.

93 Lebbé C, Ascierto P, Testori A, Bédane C, Middleton M, van Baardewijk M, Konto C, Dueymes A, Maio M: Treatment patterns and outcomes among patients diagnosed with unresectable stage III or IV melanoma in Europe: a retrospective, longitudinal survey (MELODY study). Eur J Cancer 2012;48: 3205-3214.

94 Legha SS, Ring S, Papadopoulos N, Raber M, Benjamin RS: A phase II trial of taxol in metastatic melanoma. Cancer 1990;65:24782481.

95 Einzig AI, Hochster H, Wiernik PH, et al: A phase II study of taxol in patients with malignant melanoma. Invest New Drugs 1991;9: 59-64.

96 Wiernik PH, Einzig AI: Taxol in malignant melanoma. J Natl Cancer Inst Monogr 1993; 15:185-187.

97 Zimpfer-Rechner C, Hofmann U, Figl R, et al: Randomized phase II study of weekly paclitaxel versus paclitaxel and carboplatin as second-line therapy in disseminated melanoma: a multicentre trial of the Dermatologic Cooperative Oncology Group (DeCOG). Melanoma Res 2003;13:531-536.

98 Hauschild A, Agarwala SS, Trefzer U, et al: Results of a phase III, randomized, placebocontrolled study of sorafenib in combination with carboplatin and paclitaxel as second-line treatment in patients with unresectable stage III or stage IV melanoma. J Clin Oncol 2009; 27:2823-2830.

99 Chinthakindi PK, Naicker T, Thota, N, Govender T, Kruger HG, Arvidsson PI: Gaining Momentum: Sulfonimidamides in Medicinal- and Agrochemistry. Angew Chem Int Ed DOI: 10.1002/anie.201610456. 